\section{Specific Detection of Viable Salmonella Cells by an Ethidium Monoazide-Loop Mediated Isothermal Amplification (EMA-LAMP) Method}

\author{
Yuxia Lu, ${ }^{a}$ Weiqing Yang, ${ }^{b}$ Lei Shi, ${ }^{a}$ Lin Li, ${ }^{a}$ \\ Muhammad Jahangir Alam, ${ }^{c}$ Siyuan Guo, ${ }^{a}$ \\ and Shin-ichi Miyoshi*, $d$
}

${ }^{a}$ College of Light Industry and Food Sciences, South China University of Technology, 510640, Guangzhou, China, ${ }^{b}$ Department of Clinical Microbiology, Guangdong Medical College, 524023, Guangzhou, China, ${ }^{c}$ Department of Diagnostic Medicine and Pathobiology, Kansas State University, Manhattan, KS-66506, U.S.A. and ${ }^{d}$ Graduate School of Medicine, Dentistry and Pharmaceutical Sciences, Okayama University, Tsushima-Naka, Okayama 700-8530, Japan

(Received April 16, 2009; Accepted August 7, 2009; Published online August 14, 2009)

The persistence of DNA after the cell death causes a major issue in aspects of medical or biological studies. The signal from viable bacterial cells cannot be distinguished from the dead cells in the conventional DNA-based detection methods. In the present study, the loop-mediated isothermal amplification (LAMP) method combined with the ethidium monoazide (EMA) treatment was applied for specific detection of viable, but not dead, Salmonella cells. For this method (EMA-LAMP), we designed a series of primers, which recognize six distinct sequences of the target invA gene conserved in Salmonella. The inv $A$ gene of the viable cells was remarkably amplified within $1 \mathrm{hr}$ when as small amounts as $100 \mathrm{fg}$ of DNA was subjected to EMA-LAMP. Because EMA selectively penetrated into the dead cells and bound covalently to DNA, the gene of the dead cells could not be amplified. This study offers a novel DNA-based method to distinguish the viable bacterial cells from the dead cells.

Key words — ethidium monoazide, loop-mediated isothermal amplification, Salmonella, viable cell

*To whom correspondence should be addressed: Graduate School of Medicine, Dentistry and Pharmaceutical Sciences, Okayama University, Tsushima-Naka, Okayama 700-8530, Japan. Tel.: +81-86-251-7966; Fax: +81-86-251-7926; E-mail: miyoshi@pharm.okayama-u.ac.jp

\section{INTRODUCTION}

Salmonella is a leading cause of food poisoning in humans and is also a major and important foodborne pathogen worldwide. ${ }^{1,2)}$ Many foods particularly those of animal origin or those subject to sewage are powerful vehicles for transmission of the pathogen to human beings and for spreading to the processing and kitchen environments. ${ }^{3)}$ Increased public awareness, which is related to human health and to economic impacts of food contamination, has evoked greater efforts to develop the more sensitive, rapid and inexpensive methods for detection and identification of the pathogenic microorganisms. $^{4)}$

The conventional bacteriological methods to detect Salmonella are too time-consuming while are less sensitive. Many DNA-based detection methods have been also developed in the recent years. The polymerase chain reaction (PCR) or real-time PCR technique has shown promising results due to the rapid, sensitive and specific detection of the pathogen. ${ }^{5-8)}$ Loop-mediated isothermal amplification (LAMP) is a novel DNA amplification method with ease of operation. By using this method, a few copies of the target DNA is specifically amplified to as high number as $10^{9}$ within $1 \mathrm{hr}$ under the isothermal $\left(60\right.$ to $\left.65^{\circ} \mathrm{C}\right)$ condition. However, due to the relatively long persistence of DNA after the cell death, ${ }^{9)}$ the DNA-based diagnostic methods tend to overestimate the cell numbers. ${ }^{10)}$

A new DNA-intercalating dye, ethidium monoazide (EMA), can penetrate the cell walls or membranes of the dead cells and can bind covalently to DNA. The DNA associates with EMA is not amplified by the PCR or LAMP method. ${ }^{11,12)}$ So, the method combined with the EMA treatment is possible to distinguish rapidly and conveniently the viable bacterial cells from the dead cells. In this study, the living cells of Salmonella carrying the invA gene were selectively detected by the EMA treatment followed by the LAMP method (EMA-LAMP). This indicates that EMA-LAMP may be a very rapid, highly sensitive and cost-effective method for detection of the living bacterial cells.

\section{MATERIAL AND METHODS}

Bacterial Strains and Cultivation - Two Salmonella strains, HB010 [Salmonella enterica (S. enterica) serovar Derby] and HB084 (S. enter- 


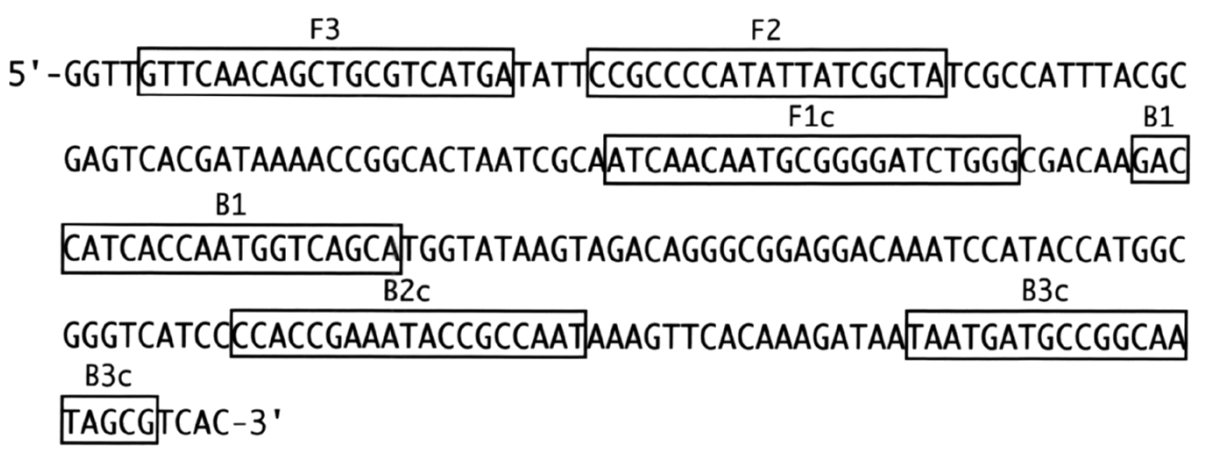

Fig. 1. The Nucleotide Sequence of the invA Gene and Primers Used for LAMP and PCR

ica serovar Indiana), which were isolated from raw chicken and raw pork respectively in Hebei province, China, were used in the present study. The bacterium was cultured overnight in $3 \mathrm{ml}$ Luria-Bertani (LB) broth (1.0\% tryptone, $0.5 \%$ yeast extract, $1.0 \% \mathrm{NaCl}, \mathrm{pH} 7.5)$ with shaking $(130$ cycles $/ \mathrm{min})$ at $37^{\circ} \mathrm{C}$. Thereafter, the bacterial culture was transferred to a centrifuge tube, and the bacterial cells were harvested, rinsed with and suspended into saline at a cell density of $5 \times 10^{8} \mathrm{CFU} / \mathrm{ml}$.

Dead Salmonella Cells — The dead cells were prepared by heat treatment or UV irradiation. For heat treatment, the living bacterial cells $\left(1 \times 10^{9} \mathrm{CFU}\right)$ in $2 \mathrm{ml}$ saline were heated at $121^{\circ} \mathrm{C}$ for $15 \mathrm{~min}$. For UV treatment, the living cells $\left(5 \times 10^{9} \mathrm{CFU}\right)$ in $10 \mathrm{ml}$ saline were irradiated with a $40 \mathrm{~W}$ UVC lamp for 0 to $30 \mathrm{~min}$ in a petri dish. ${ }^{13,14)}$ During irradiation, the lamp was placed at $35 \mathrm{~cm}$ from the bacterial cells, and the bacterial cell suspension was agitated to avoid sedimentation of the cells.

EMA Treatment — The viable or dead cells in a centrifuge tube $\left(5 \times 10^{8}\right.$ cells $\left./ \mathrm{ml}\right)$ were treated with EMA (Biotium Inc., Hayward, China) in the dark for $10 \mathrm{~min}$ and were subsequently exposed to a $650 \mathrm{~W}$ halogen lamp for $90 \mathrm{~s}$. The lamp was placed at about $15 \mathrm{~cm}$ from the bacterial cells, which were cooled in the ice bath to minimize the elevation of temperature. ${ }^{12)}$ After EMA treatment, the bacterial cells were harvested and rinsed with saline.

Preparation of Bacterial DNA — - To prepare the bacterial DNA, the viable or dead Salmonella cells $\left(1 \times 10^{9}\right.$ cells in $2 \mathrm{ml}$ saline $)$ were collected by centrifugation and resuspended into $0.2 \mathrm{ml}$ distilled water. Thereafter, the bacterial cell suspension was boiled for $10 \mathrm{~min}$.

EMA-LAMP — A serious of primers targeted six distinct regions in the invA gene, a Salmonella specific gene, ${ }^{15-18)}$ was designed for the EMALAMP method (Fig. 1). The sequences were analyzed by the Primer Explorer V4 software program (http://primerexplorer.jp/e/index.html) to design invA-F3: $5^{\prime}$-gttcaacagctgcgtcatga-3' (a forward outer primer), invA-B3: $5^{\prime}$-cgctattgccggcatcatta- $3^{\prime}$ (a backward outer primer), invA-FIP: $5^{\prime}$-cccagatcccegcattgttgat $t t t t c c g c c c c a a t a t t a t c g c t a-3^{\prime}$ (a forward inner primer), and invA-BIP: 5'-gaccatcaccaatggtcagcattttattggcggtatttcggtgg-3' (a backward inner primer). The forward inner primer, invA-FIP, consisted of the complementary sequence of $\mathrm{F} 1$, a TT-T-T linker and F2. The backward inner primer, invA-BIP, consisted of B1, a T-T-T-T linker and the complementary sequence of $\mathrm{B} 2$. The outer primers, invA-F3 and invA-B3, were located outside of the F2 and $\mathrm{B} 2$ regions, respectively.

The EMA-LAMP experiment was carried out in a total of $50 \mu \mathrm{l}$ reaction mixture following the published procedure, ${ }^{15)}$ and the reaction was terminated by heating at $85^{\circ} \mathrm{C}$ for $5 \mathrm{~min}$. Thereafter, SYBR Green I was added to the product to observe the color change. The green color represents the positive result, while orange color represents the negative result.

PCR — The PCR experiment was performed with two outer primers, invA-F3 and invA-B3 (Fig. 1). The reaction mixture $(50 \mu \mathrm{l})$ contained $5 \mu \mathrm{l}$ of the buffer $(100 \mathrm{mM}$ Tris- $\mathrm{HCl}, 500 \mathrm{mM} \mathrm{KCl}$, $15 \mathrm{mM} \mathrm{MgCl} 2, \mathrm{pH} 8.3), 3 \mu \mathrm{l}$ (30 pmol) of each of the primers, $4 \mu \mathrm{l}$ of $2.5 \mathrm{mM}$ dNTPs mixture, $3 \mu \mathrm{l}$ of the template DNA and $0.25 \mu \mathrm{l}(1.25 \mathrm{U})$ of rTaq DNA polymerase. The thermal profile was $94^{\circ} \mathrm{C}$ for $5 \mathrm{~min}$ (heat treatment), followed by 30 cycles of $94^{\circ} \mathrm{C}$ for $30 \mathrm{~s}$ (denaturation), $53^{\circ} \mathrm{C}$ for $30 \mathrm{~s}$ (annealing), and $72^{\circ} \mathrm{C}$ for $20 \mathrm{~s}$ (extension), and a final extension at $72^{\circ} \mathrm{C}$ for $7 \mathrm{~min}$. The products were analyzed by electrophoresis in $1.2 \%$ agarose gel and visualized by staining with ethidium bromide. 


\section{A: LAMP}
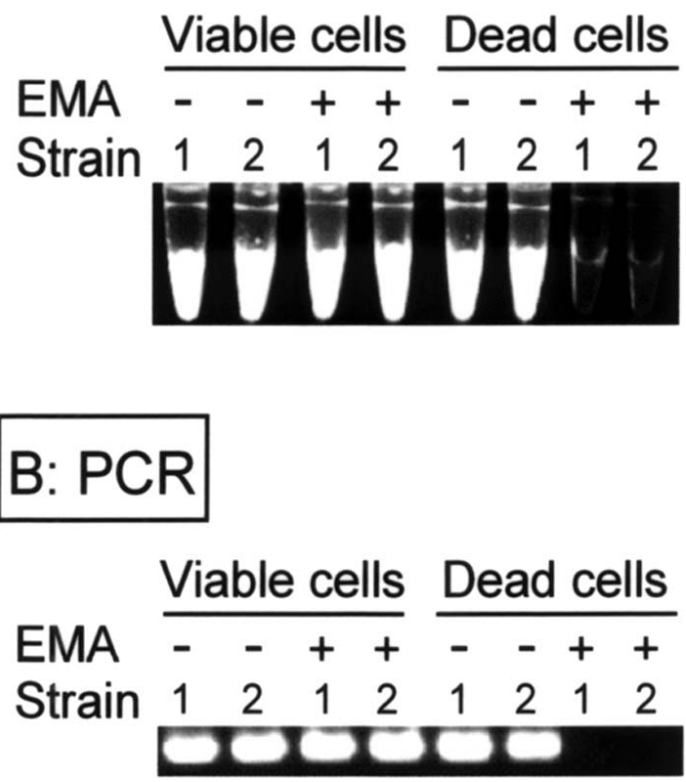

Fig. 2. Detection of the Salmonella Cells by LAMP or PCR The viable or dead cells $\left(5 \times 10^{8}\right.$ cells/ml $)$ were prepared from strain HB010 (1) or HB084 (2). Thereafter, the cells were treated with or without EMA and subjected to LAMP (A) or PCR (B).

\section{RESULTS}

The dead cells of Salmonella were treated or untreated with EMA and subjected to LAMP or PCR. The invA gene of the EMA-untreated cells was apparently amplified; however, the gene of the EMAtreated cells was not amplified by LAMP as well as by PCR (Fig. 2). On the other hand, the invA gene of the viable cells was amplified even though treated with EMA (Fig. 2). These results indicate the EMA treatment is useful for the specific detection of the living cells by LAMP or PCR because EMA enters selectively to the dead cells. Although both EMALAMP and EMA-PCR showed sufficient amplification of the invA gene, the former offered the results more rapidly. In PCR, a total of $3 \mathrm{hr}$ or more was needed for achievement of the experiments (DNA amplification, gel electrophoresis and visualizing with ethidium bromide). By contrast, the LAMP experiment including DNA amplification and visualizing with SYBR Green I was completed within $1 \mathrm{hr}$.

When the living cells of strain HB010 were irradiated with a UV lamp, the numbers of the cultivable cells were drastically decreased. At 5-min irradiation, the numbers of the colonies formed were

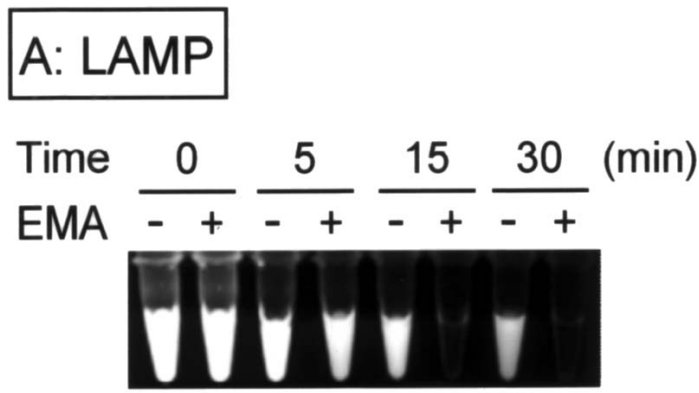

\section{B: PCR}

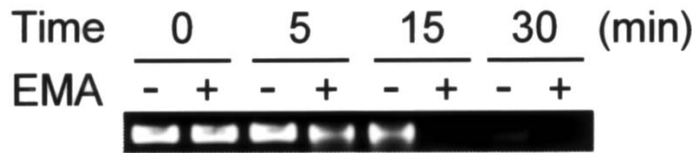

Fig. 3. Effect of UV Irradiation on the Detection of the Salmonella Cells by LAMP or PCR

The cell suspension of strain HB010 $\left(5 \times 10^{8} \mathrm{CFU} / \mathrm{ml}\right)$ was irradiated with a UV lamp for 0 to $30 \mathrm{~min}$. Thereafter, the cells were treated with or without EMA and subjected to LAMP (A) or PCR (B).

reduced to only $0.1 \%$, while at 15 -min irradiation, no cultivable cell was detected (data not shown). As shown in Fig. 3, in both LAMP and PCR experiment, no amplification of the invA gene was observed at 15 -min irradiation when pretreated with EMA, indicating the total killing of the Salmonella cells. The 5-min irradiated sample showed the positive results even when pretreated with EMA. However, when diluted 500-fold before the LAMP or PCR experiment, no amplicon was detected only in the EMA-pretreated sample (data not shown). The result also showed that the 30-min irradiation caused destruction and fragmentation of the bacterial DNA because the signal of the amplicon was apparently decreased in the sample without the EMApretreatment.

In order to compare the sensitivity, various amounts of DNA prepared from the EMA-treated living Salmonella cells were subjected to EMALAMP or EMA-PCR. The detection limit of the LAMP assay was as low as $100 \mathrm{fg}$ DNA, which is equivalent to only 10 cells of the pure culture, while that of the PCR assay was $100 \mathrm{pg}$ to $1 \mathrm{ng}$ (Fig. 4).

\section{DISCUSSION}

Both PCR and real-time PCR have been very useful techniques for Salmonella detection. In the 


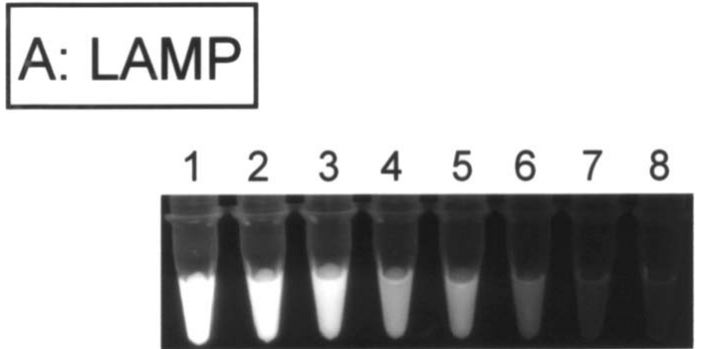

\section{B: PCR}

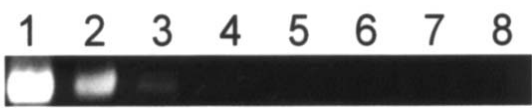

Fig. 4. Comparison of the Sensitivity of EMA-LAMP to EMA-PCR

The DNA prepared from strain HB010 was treated with EMA and subjected to LAMP (A) or PCR (B). Lane 1, $10 \mathrm{ng}$ DNA; lane 2, $1.0 \mathrm{ng}$ DNA; lane 3, 100 pg DNA; lane 4, $10 \mathrm{pg}$ DNA; lane 5, $1.0 \mathrm{pg}$ DNA; lane 6,100 fg DNA; lane 7, 10 fg DNA; and lane 8, without DNA.

PCR experiment, the size of the product is revealed by electrophoresis using an agarose gel. Thus, the validity of the amplification is visually confirmed. On the other hand, the real-time PCR has many advantages such as rapidity, low contamination, higher sensitivity and easy standardization. However, because of requirement of the fluorogenic primers and probes as well as the expensive detection equipments, employment of the real-time PCR technique has restricted only in the laboratories with good financial resources. ${ }^{19)}$ Moreover, it should be emphasized that both PCR and real-time PCR can not distinguish the viable cells from the dead cells. The results of the present study demonstrated that the EMA treatment might be suitable for the selective detection of viable Salmonella cells by PCR.

The EMA-LAMP method developed herein requires no sophisticated equipment except for a water bath, and this technique can rapidly discriminate only the viable cells. Additionally, EMP-LAMP is more sensitive than other DNA-based detection techniques. It has been also documented that, during the EMA-LAMP experiment, much pyrophosphate ions are generated and white precipitates of magnesium pyrophosphate are formed through reaction with magnesium ions in the reaction mixture..$^{20,21)}$ This allows the easy and rapid confirmation of amplification of the target gene without visualizing by SYBR Green I.
The present study may be the first report on the application of EMA-LAMP for detection of the viable Salmonella cells. The EMA-LAMP method is potentially useful to all of the biological or medical diagnostic studies for distinction between the viable and dead cells. ${ }^{22)}$ Therefore, the EMA-LAMP technique may provide an efficient new approach for testing of the food safety. However, the enrichment cultivation using the selective broth, ${ }^{23)}$ as well as some modifications of the experimental procedures including DNA isolation, design of the primers and EMA treatment, might be required for suitable detection of a very low numbers of Salmonella cells from the food or feed sample.

Acknowledgements This study was supported by the National Natural Science Foundation of China (20877028), the Science Foundation of the Ministry of Education of China (706046) and the Technology Planning Project of Zhuhai City (PC20082034).

\section{REFERENCES}

1) Gomez, T. M., Motarjemi, Y., Miyagawa, S., Kaferstein, F. K. and Stohr, K. (1997) Foodborne Salmonellosis. World Health Stat. Q., 50, 81-89.

2) Tirado, C. and Schmidt, K. (2001) WHO surveillance programme for control of foodborne infections and intoxications: results and trends across greater Europe. J. Infect., 43, 80-84.

3) Wallace, D. J., Van Gilder, T., Shallow, S., Fiorentino, T., Segler, S. D., Smith, K. E., Shiferaw, B., Etzel, R., Garthright, W. E. and Angulo, F. J. (2000) Incidence of foodborne illnesses reported by the foodborne diseases active surveillance network (FoodNet)-1997. J. Food Prot., 63, 807-809.

4) Whyte, P., Gill, K. M., Collins, J. and Gormley, D. E. (2002) The prevalence and PCR detection of Salmonella contamination in raw poultry. Vet. Microbiol., 89, 53-60.

5) Malorny, B., Bunge, C. and Helmuth, R. (2007) A real-time PCR for the detection of Salmonella Enteritidis in poultry meat and consumption eggs. $J$. Microbiol. Methods, 70, 245-251.

6) Oliveira, S. D., Santos, L. R., Schuch, D. M. T., Silva, A. B., Salle, C. T. P. and Canal, C. W. (2002) Detection and identification of Salmonella from poultry-related samples by PCR. Vet. Microbiol., 87, 25-35.

7) Perelle, S., Dilasser, F., Malorny, B., Grout, J., Hoorfar, J. and Fach, P. (2004) Comparison of PCR- 
ELISA and LightCycler real-time PCR assays for detecting Salmonella spp. in milk and meat samples. Mol. Cell. Probes, 18, 409-420.

8) Seo, K. H., Valentin-Bon, I. E. and Brackett, R. E. (2006) Detection and enumeration of Salmonella enteritidis in homemade ice cream associated with outbreak: comparison of conventional and real-time PCR methods. J. Food Prot., 69, 639-643.

9) Klerks, M. M., Zijlstra, C. and Van Bruggen, A. H. C. (2004) Comparison of real-time PCR methods for detection of Salmonella enterica and Escherichia coli $\mathrm{O} 157: \mathrm{H7}$, and introduction of a general internal amplification control. J. Microbiol. Methods, 59, 337-349.

10) Andreas, N., Cheung, C. Y. and Anne, K. C. (2006) Comparison of propidium monoazide with ethidium monoazide for differentiation of live vs. dead bacteria by selective removal of DNA from dead cells. $J$. Microbiol. Methods, 67, 310-320.

11) Nocker, A. and Camper, A. K. (2006) Selective removal of DNA from dead cells of mixed bacterial communities by use of ethidium monoazide. Appl. Environ. Microbiol., 72, 1997-2004.

12) Knut, R., Birgitte, M., Signe, M. D. and Askild, L. H. (2005) Use of ethidium monoazide and PCR in combination for quantification of viable and dead cells in complex samples. Appl. Environ. Microbiol., 71, 1018-1024.

13) Michael, Y. R., Christian, W. and Ulrike, H. L. (2006) Impact of ultraviolet radiation on cell structure, UV-absorbing compounds, photosynthesis, DNA damaging, and germination in zoospores of Arctic Saccorhiza dermatodea. J. Exp. Bot., 57, 3847-3856.

14) Luis, R. M. and Arturo, C. (2007) Cryptococcus neoformans biofilm formation depens on surface support and carbon source and reduces fungal cell susceptibility to heat, cold, and UV light. Appl. Environ. Microbiol., 73, 4592-4601.

15) Li, W., Lei, S., Alam, M. J., Geng, Y. H. and Li, L. (2008) Specific and rapid detection of foodborne Salmonella by loop-mediated isothermal amplification method. Food Research International,
41, 69-74.

16) Naravanene, R. and Jamil, K. (2005) Rapid detection of food-borne pathogens by using molecular techniques. J. Microbiol., 54, 51-54.

17) Ohtsuka, K., Yanagawa, K., Takatori, K. and Hara-kudo, Y. (2005) Detection of Salmonella enterica in naturally contaminated liquid eggs by loopmediated isothermal amplification, and characterization of Salmonella isolates. Appl. Environ. Microbiol., 71, 6730-6735.

18) Rahn, K., Grandis, S. A. D., Clarke, R. C., McEwen, S. A., Galan, J. E., Ginocchio, C., Curtiss III, R. and Gyles, C. L. (1992) Amplification of an invA gene sequence of Salmonella Typhimurium by polymerase chain reaction as a specific method of detection of Salmonella. Mol. Cell. Probes, 6, 271-279.

19) Parida, M., Horioke, K., Ishida, H., Dash, P. K., Saxena, P., Jana, A. M., A Islam, M., Inoue, S., Hosaka, N. and Morita, K. (2005) Rapid detection and differentiation of dengue virus serotypes by a real-time reverse transcription-loop-mediated isothermal amplification assay. J. Clin. Microbiol., 43, 2895-2903.

20) Mori, Y., Nagamine, K., Tomita, N. and Notori, T. (2001) Detection of loop mediated isothermal amplification reaction by turbidity derived from magnesium pyrophosphate formation. Biochem. Biophys. Res. Commun., 289, 150-154.

21) Alkan, N., Gadkar, V., Yarden, O. and Kapulnik, Y. (2006) Analysis of quantitative interactions between two species of arbuscular mycorrhizal fungi (AMF), Glomus mosseae and G. intraradices by real-time PCR. Appl. Environ. Microbiol., 72, 4192-4199.

22) Vijay, G. and Matthias, C. R. (2008) Evaluation of loop-mediated isothermal amplification (LAMP) to rapidly detect arbuscular mycorrhizal fungi. Soil Biol. Biochem., 40, 540-543.

23) Burkhard, M., Charlotta, L., Martin, W., Nadine, K. and Jeffrey, H. (2008) Enumeration of Salmonella bacteria in food and feed samples by real-time PCR for quantitative microbial risk assessment. Appl. Environ. Microbiol., 73, 1299-1304. 